\title{
MANAGING WATER QUALITY IN A POLLUTED LAKE OF SOUTHEAST BRAZIL
}

\author{
MARCELO MOTTA VEIGA ${ }^{1,2}$, DALTON MARCONDES SILVA ${ }^{1} \&$ LILIAN BECHARA ELABRAS VEIGA $^{3}$ \\ ${ }^{1}$ Environmental Health Department, National School of Public Health, Oswaldo Cruz Foundation, Brazil. \\ ${ }^{2}$ Strategic Management Department, Business School, Federal University of Rio de Janeiro State, Brazil. \\ ${ }^{3}$ Energy Planning Program, Rio de Janeiro Federal University, Brazil.
}

\begin{abstract}
Brazil has been suffering from lack of sanitation infrastructure. Great part of domestic sewages does not receive any treatment before final discharge. This study analyzed water quality in Javary Lake, located in Southeastern Brazil. Over decades, this water resource has been progressively polluted due to the raw domestic sewage discharges from local residences. Most of the organic matter introduced in the Lake was already consumed by organisms or has biodegraded. Physico-chemical and microbiological results from 2007 to 2010 corroborated the 'polluted' status of the Javary Lake, mainly by organic matter. An aggregate analysis of the overall results indicates that they were similar to values typically observed in stabilization ponds. These results support the main assumption of this study, which implied that the Lake has been biologically operating as a stabilization pond for a long time. There is an ongoing public project to clean up Javary Lake. Since 2011, there is no more domestic raw sewage being directly discharged. However, a significant portion of the sludge has deposited on the bottom of the Lake. In 2011, there was an attempt to remove this accumulated sludge. This attempt of sludge removal introduced already settled down organic matter into the water, generating algae bloom and fish death. Thus, the sludge dredging operation was interrupted. After this faulty dredging, this study did a follow-up analysis indicating that Javary Lake was still polluted. To reverse this situation, it is still necessary to control the recently implemented sewage treatment system and to dredge the Lake bottom to remove most of the accumulated sludge. Till date, Javary Lake still keeps its 'polluted' status. It is still pending further studies to determine what would be the best alternative for managing the water quality in the Lake and for disposing the sludge.

Keywords: water quality, sewage, stabilization ponds, Brazil, pollution.
\end{abstract}

\section{INTRODUCTION}

The World Health Organization (WHO) stresses the close relationship between health and water quality. The lack of adequate systems for water supply, sewage collection, and treatment directly affects the health of the population and the entire ecosystem. Indeed, a large percentage of diseases affecting developing countries can be related to poor sanitation system. For this reason, proper water management is one of the most efficient measures to improve human and environmental health.

It is estimated that $12 \%$ of the world's available water resources are located in Brazil (around $179,000 \mathrm{~m}^{3} / \mathrm{s}$ ), which corresponds to $53 \%$ of South America's water resources [1]. For a long time, the notion of water abundance built up the Brazilian culture for extravagance, postponing necessary investments to develop technologies for an efficient use and protection of water resources [1].

As Rebouças [1] and Braga et al. [2] have stated, Brazilian water management problems derives mainly from a combination of uncontrolled population growth, unplanned urban scenario, industrialization, and agricultural expansion, making both the quality and the quantity of water supply vulnerable.

In Brazil, due to the lack of adequate sewage collection and treatment systems, it is common for untreated domestic and/or industrial effluents to be discharged directly into water bodies. This often occurs through clandestine release of sewage into storm drainage systems. As can be deduced, this situation has been causing serious problems to human health as well as to the environmental quality of rivers, lakes, ponds, lagoons, bays, and offshore waters. 
Thus, poor sanitation infrastructure is a major concern for Brazilian public officials. A proper sanitary system has a strong impact on reducing water-related diseases and infant mortality. The Brazilian National Water Agency [3-5] stated that the discharge of raw sewage in water resources is the main cause for environmental degradation in Brazil.

In fact, according to the National Survey of Basic Sanitation (PNSB) by the Institute of Geography and Statistics, only 55.2\% of Brazilian municipalities have some kind of domestic sewage collection system, out of which, around one-thirds of these municipalities did not receive any treatment before final discharge into water resources. In most municipalities, raw sewage is directly released into water bodies [6].

Given this situation, it could be inferred that there is a considerable amount of organic matter being improperly released in Brazilian waters. In fact, the improper release of raw domestic sewage directly affects the availability of water (quantity and quality) endangering its multiple uses, population health, and ecosystem as a whole [6].

In 2007, a National Sanitation Policy was enacted through a formal federal law (Law 11,445/07) establishing a regulatory framework for the sanitation sector [7]. This rule defined national guidelines and was innovative for the Brazilian sanitary system by introducing the basis for future policies and regulations to guide the whole sector, trying to encourage new public and private sectors investments.

Another important water quality rule is the Resolution 357/2005 enacted by the Brazilian National Environmental Council (CONAMA), which established guidelines for classifying water bodies according to their most important uses, aiming to establish mandatory water quality standards (WQSs), including 13 water classes. Each one of these classes was defined according to the water quality required for complying with each designated use [8].

This rule also defines physical and biochemical WQS for a list of contaminants and substances, for example, biochemical oxygen demand (BOD), dissolved oxygen (DO), floating materials, oils and greases, and solid objectionable waste. BOD is a parameter for measuring the potential pollution of certain biodegradable substances in relation to DO consumption. DO values are essential to assess the natural condition of water and to assess environmental impacts (e.g. eutrophication and pollution) caused by organic matter discharge [9].

Recently, in May of 2011, CONAMA enacted a new rule (Resolution 430/11) complementing Resolution 357/05 in respect of sewage discharges in water bodies. This new rule established stricter conditions, standards, and guidelines for managing effluent (domestic and industrial) discharges on water bodies. According to the new rule, the effluent from any source may only be discharged directly or indirectly into a water body after being properly treated [10].

Other important legislations for managing water quality in Brazil are: Drinking Water Rule (Administrative rule 518/2004) enacted by the Ministry of Health, stating standards for drinking water [11]; and CONAMA Resolution 274/2000, which states standards for any water resources (river, lake, lagoon, ocean, sea, etc.) that have the possibility to be in touch with human beings or animals [12].

This study assessed water quality of a polluted water resource, named Javary Lake, located in southeastern Brazil. Javary Lake is the main natural attraction of a pleasant touristic region. It has a shoreline of slightly over $2 \mathrm{~km}$ and a water surface area of $80,000 \mathrm{~m}^{2}$ even though its watershed covers $3.74 \mathrm{~km}^{2}$. Water depth varies from 1 to $4 \mathrm{~m}$. Besides its relevance for recreational activities, the Lake is important for its scenic beauty, drainage, and ecological role on the region. This study collected several water samples from 10 points along its shoreline. These points were selected based on accessibility, coverage, and relevance.

The municipality where Javary Lake is located has an urbanization rate of $84 \%$, a total area of $288.8 \mathrm{~km}^{2}$ and a local population of around 30,000 people, in which $33 \%$ (10,000 people) are directly 


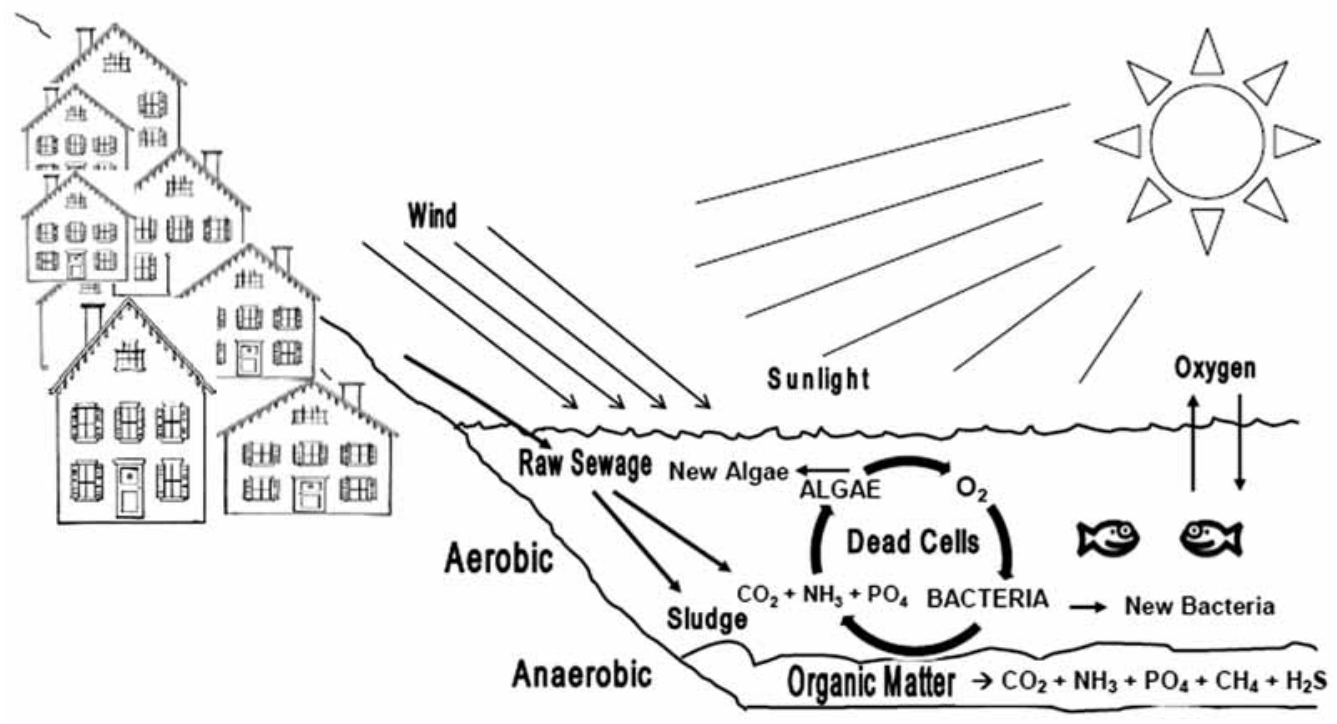

Figure 1: Schematic polluted Javary Lake as a stabilization pond.

responsible for polluting this water resource [13]. Because of its location in the high mountains at inland part of Rio de Janeiro State, around $700 \mathrm{~m}$ in altitude, its climate is cooler than on the coast, making it a popular touristic destination, especially in the hot summer season.

In the municipality, $24.6 \%$ of residences have piped water, $73.7 \%$ obtain their water from wells or springs, and the remaining $1.7 \%$ get their water from other sources. The municipal sewer collection system only serves $13.5 \%$ of the dwellings, while $65.3 \%$ have proper septic tanks, $10.7 \%$ use rudimentary septic pits, $7.5 \%$ are connected to uncovered ditches, and $2.5 \%$ discharge their sewage directly into a water body. However, no sewage collected received treatment before discharge into water bodies [13].

Despite its local importance, the Javary Lake has been progressively polluted over decades, mainly by raw domestic sewage discharge. It is estimated that there is a layer of $1.5 \mathrm{~m}$ of sludge (organic matter) set down on the bottom of the Lake. The preliminary laboratory results confirmed this polluted status indicating that its water quality seemed to be the typical values found in stabilization ponds, see Fig. 1.

\section{MATERIALS AND METHODS}

Preliminarily, in 2007 and 2008, this study collected water samples from 10 points along the entire Lake shoreline. In this preliminary analysis, this study collected six samples in each of the 10 selected points, assessing $\mathrm{pH}$, conductivity, DO, salinity, and total dissolved solids, using a Hanna Instruments model HI-9828 multiparameter (in site). This study then took the remainder of these samples to the laboratory to evaluate the chemical oxygen demand (COD), BOD and nitrates, according to the procedure recommended in the Standard Methods [14-16].

In 2007, the results of these first analyses indicated the presence of high levels of organic materials. For this reason, in 2008, it was designed a second round study to assess the characteristics of this organic load in more detail, by analyses of fecal coliforms and total coliforms using ChromoCult $^{\circledR}[16]$. 
The outcome of this lack of sewage treatment reflected in the findings of this study, which revealed various problems of environmental health in the region, mainly associated with raw sewage. The physico-chemical and microbiological analyses performed showed that the Lake is polluted mainly by organic matter (domestic sewage). However, the COD/BOD ratio at some sampling points did not rule out the possibility of contamination by industrial wastewater [17].

In 2009, the local government decided to implement a cleaning up project to reduce pollution in the Javary Lake. This US $\$ 15$ million project included a sewage treatment facility and $25 \mathrm{~km}$ of collection pipeline.

In 2010, this study performed several fecal coliform analyses to assess organic matter polluting Javary Lake, using ChromoCult ${ }^{\circledR}$. The main reason for this new set of laboratory analysis was to confirm its polluted status.

In 2011, the first part of the cleaning-up project was concluded and most of the domestic sewage discharge into the Javary Lake was collected and treated. Also, in the second semester of 2011, an attempt to remove sludge from the bottom of Javary Lake generated algae bloom and fish death. The sludge dredging was interrupted.

This study performed a follow-up study to analyze, preliminarily, the new water quality of Javary Lake, after the implementation of the cleaning-up project and the sludge removal attempt. Instead of analyzing the fecal coliform to evaluate the organic matter existent in the water, this study used the enzymatic method (Colilert) to assess the presence of $E$. coli.

\section{RESULTS}

\subsection{Preliminary results $-2007,2008$, and 2010 [16]}

These preliminary results showed a worrying degradation of the water quality in Javary Lake. The results indicated that the contamination consisted mainly of organic material, possibly from raw domestic sewage, causing serious eutrophication of the Lake [16].

According to CONAMA Resolution 357/2005 [8], water intended for human consumption after conventional or advanced treatment, as well as for irrigation of crops that will not be eaten raw, sport fishing, recreation with secondary contact (partial body contact, such as boating), and watering of animals, is categorized as class 3 .

The highest allowable $\mathrm{BOD}_{5}$ level for this class of water is $10 \mathrm{mg} / \mathrm{L}$. Almost all the water samples exceeded this threshold. Only the samples from one point were below this level.

However, the water quality in Javary Lake should be classified as class 1 or class 2, due to its use by tourists and residents for activities involving primary contact (full body contact, such as swimming and wading). In these cases, Resolution 357/2005 sets the maximum $\mathrm{BOD}_{5}$ limits at 3 and $5 \mathrm{mg} / \mathrm{L}$, respectively. All the sample values were above these limits and some of them were well above $100 \mathrm{mg} / \mathrm{L}$, which is typical of light domestic sewage. These values demonstrated that the organic load, introduced by raw sewage discharge, exceeds the Lake's capacity for dilution and biodegradation, which is low because it is a lentic body.

The COD values and the COD/BOD ratio in most cases also indicated the introduction of industrial wastes. Although there were no industrial activities in the region, there are various commercial establishments that produce effluents with industrial characteristics, such as car repair shops, lumber yards, gas service stations, and cabinet making shops [15, 16].

High nitrate levels are associated with the occurrence of eutrophication. Water with nitrate concentration above $10 \mathrm{mg} / \mathrm{L}$ is considered unfitted for human consumption. This is the maximum value permitted for classes 1,2 , and 3 according to the rule [8]. Only two values were lower than 
$10 \mathrm{mg} / \mathrm{L}$. The levels found indicate decomposition of the organic matter introduced into the Lake through sewage discharge, again aggravated by the fact that it is a lentic water body. Such water bodies generally require removal of nutrients (nitrogen and phosphorous) through water treatment to reduce eutrophication.

In 2008, this study also performed various analyses of thermo-tolerant and total coliforms to check for compliance with the Resolution 274/2000. The thermo-tolerant coliform values found were all greater than the maximum level (satisfactory category) permitted for contacting with humans, which is 1,000 coliforms $/ 100 \mathrm{~mL}$. These results demonstrated that the water in Javary Lake was contaminated and unfitted for human primary contact [16].

Among the parameters analyzed with the multiparameter meter, the DO was particularly high, indicating intense production of oxygen by algae (Fig. 1). This high DO concentration inhibits the occurrence of unpleasant odors, typical of anaerobic environments, and favors biodegradation of organic matter.

Javary Lake is in the process of sludge sedimentation and anaerobiosis. The high eutrophication can provide favorable conditions for algal blooms, which might include cyanobacteria. The DO results were similar to those observed in stabilization ponds (Fig. 1), which are designed and constructed specifically for treating raw sewage. This type of ponds normally need to be drained and dredged every 20 or 30 years to maintain their water volume and treatment capacity. On the other hand, stabilization ponds do not require large capital investments, high maintenance and operational costs, and special technical skills to operate. However, they do require long detention process and large areas, and also they blow out odors, which should limit drastically their use. These constraints make stabilization ponds a rare occurrence in densely populated areas, such as, southeast region of Brazil [16].

In the second phase of the study (2008), the total and thermo-tolerant coliform levels were analyzed to assess the characteristics of this organic load. The main component of this group is E. coli, although some coliforms of the Klebsiella genus also have this capacity.

The presence of coliform bacteria has been extensively used to assess water quality. Their levels serve as a basic microbiological parameter, as indicators of fecal pollution, because they are always present in the intestinal tract of humans and other warm-blooded animals and are eliminated in large quantities in the feces. Hence, these levels are included in the water quality regulations of many countries, including Brazil. The presence of coliforms in water indicates pollution with a risk of the presence of pathogenic organisms, since they are more resistant in water than pathogenic bacteria of intestinal origin.

Therefore, this study also carried out various analyses of thermo-tolerant and total coliforms to check for compliance with the applicable regulations (Resolutions 274/00 and 357/05) [8, 12]. The levels of thermo-tolerant coliforms per $100 \mathrm{~mL}$ were found much higher than the maximum concentration (satisfactory category) permitted by these regulations, which is 1,000 coliforms $/ 100 \mathrm{~mL}$. This finding demonstrates that the Lake's water is highly contaminated and unfit for recreation where there is the possibility of primary contact.

Resolution 357/05 [8] establishes the water quality conditions through limits for thermo-tolerant coliforms. For fresh water class 3 , which is considered suitable for recreation with secondary (eventual) contact, the limit is 2,500 thermo-tolerant coliforms $/ 100 \mathrm{~mL}$. For watering of animals raised in confined spaces, the limit is 1,000 coliforms $/ 100 \mathrm{~mL}$, and for other uses the limit is 4,000 coliforms.

In three sampling points, all located near the center of the Lake that allowed greater dilution, the results were within legal limits for fresh water class 2 . The other values found can be characterized as indicating environmental contamination typical of raw sewage. 
The levels of DO and saturation percentage in the two collections where these parameters were analyzed, presented very wide variation. The saturation ranged from 0.84 to $11.94 \%$. Very low values, near zero, are associated with anaerobic conditions at the Lake bottom, and very high ones, near the saturation value, are associated with the presence of algae, and hence of eutrophic conditions. Fish cannot live in water with levels below $3 \mathrm{mg} / \mathrm{L}$, and freshwater fish typically require DO levels above $5 \mathrm{mg} / \mathrm{L}$. According to Resolution 357/2005 [8], classes 1 and 2 fresh water bodies must have DO levels of at least 6 and $5 \mathrm{mg} / \mathrm{L}$, respectively.

As can be seen in Table 1, the DO levels in the water samples from the first collection were very high, above the saturation value, indicating the presence of algae and a eutrophic condition. In the second collection, none of the values obtained satisfied the legal requirements for classes 1 and 2 . In fact, the values obtained in Javary Lake did not even meet the requirement for class 4, which is water after the discharge of treated sewage.

The $\mathrm{pH}$ values of a water body are associated with the corresponding $\mathrm{pH}$ levels of the soil in its drainage area, the sediment in its bed, the rainwater that falls in the area, and the effluents flowing into it, as well as of the presence of algae. The discharge of domestic sewage tends to lower the $\mathrm{pH}$ level of water bodies.

On the other hand, the presence of algae tends to raise the $\mathrm{pH}$ values because they consume carbonate to multiply. The combination of these antagonistic effects helps explain the great variability of the $\mathrm{pH}$ values found, which ranged between 6.57 and 10.11. Most fish species can live in water with $\mathrm{pH}$ in the range of 6-9. In aerobic or stabilization ponds, the $\mathrm{pH}$ values are generally above 8 , the same as for eutrophized water bodies (Fig. 1).

In general, the results indicated that points with the highest DO value also had high $\mathrm{pH}$ levels. The wide range of $\mathrm{DO}$ and $\mathrm{pH}$ values can indicate an expected variation according to sunlight (morning, afternoon, evening), season (warm and cold), and difference in the pattern and in the amount of sewage discharged into Javary Lake. There are other pertinent factors to be considered as well, such as dilution by rainfall, water depth, among other environmental variables.

Table 1: Dissolved oxygen, saturation percentage, and $\mathrm{pH}$ results.

\begin{tabular}{ccccccc}
\hline \multicolumn{7}{c}{ DO (mg/L), saturation percentage and $\mathrm{pH}$} \\
\hline \multicolumn{7}{c}{ 2007 - Collection } \\
\cline { 2 - 7 } Point & \multicolumn{7}{c}{ 1st } & pH & DO & Sat. \% & pH \\
\cline { 2 - 6 } 1 & DO & Sat. \% & 9.11 & 2.74 & 34.8 & 7.40 \\
2 & 6.65 & 87.3 & 7.46 & 2.60 & 32.4 & 7.07 \\
3 & 1.46 & 19.5 & 7.67 & 2.43 & 30.2 & 7.31 \\
4 & 3.41 & 44.3 & 7.38 & 0.84 & 10.2 & 6.57 \\
5 & 3.87 & 52.4 & 7.15 & 2.30 & 27.9 & 7.05 \\
6 & 0.86 & 10.9 & 9.01 & 2.06 & 26.3 & 7.60 \\
7 & 4.46 & 58.6 & 9.55 & 1.47 & 19.0 & 7.90 \\
8 & 6.93 & 90.9 & 10.11 & 2.70 & 34.9 & 8.41 \\
9 & 11.94 & 162.1 & 7.10 & 3.48 & 43.2 & 8.07 \\
10 & 3.77 & 51.3 & 9.93 & 1.89 & 24.0 & 7.98 \\
\hline
\end{tabular}


Table 2: Total ammonia nitrogen.

\begin{tabular}{lrrrrrr}
\hline \multicolumn{7}{c}{${\mathrm{N}-\mathrm{NH}_{3}-\text { in } \mathrm{mg} / \mathrm{L}}^{7}$} \\
\hline \multicolumn{7}{c}{$2007-$ Collection } \\
Point & \multicolumn{7}{c}{ 1st } & 2nd & 3rd & 4th & 5 th & 6th \\
\hline 1 & 2.16 & 0.70 & 1.37 & 1.40 & 0.68 & 2.98 \\
2 & 108.93 & 20.46 & 17.74 & 6.79 & 14.96 & 18.08 \\
3 & 112.67 & 20.63 & 18.11 & 7.86 & 15.54 & 19.03 \\
4 & 74.45 & 13.51 & 4.98 & 2.16 & 3.05 & 3.22 \\
5 & 85.74 & 14.36 & 14.89 & 6.33 & 11.69 & 13.65 \\
6 & 2.32 & 0.46 & 0.09 & 1.13 & 0.47 & 0.21 \\
7 & 2.15 & 0.09 & 0.06 & 0.70 & 0.49 & 0.17 \\
8 & 1.90 & 0.10 & 0.06 & 0.59 & 0.32 & 0.14 \\
9 & 13.31 & 2.63 & 1.61 & 0.72 & 0.69 & 0.63 \\
10 & 1.55 & 0.10 & 0.39 & 0.61 & 0.29 & 0.10 \\
\hline
\end{tabular}

DO percentage saturation values between 80 and $120 \%$ are considered excellent. DO values of $<60 \%$ or $>125 \%$ are considered to be poor. Supersatured percentage of DO (shaded in Table 1) can be harmful to fish and other aquatic organisms.

Some of the total ammonia nitrogen values, presented in Table 2, were very high, not meeting the legal standards (Resolution 357/2005) [5]. Some of these values (shaded) even exceeded those typical of raw sewage, of 20 to $40 \mathrm{mg} / \mathrm{L}$ [16].

These findings are probably due to the decomposition of organic material, which is converted first into ammonia and to the process of accumulation of nutrients aggravated because of the Javary Lake's lentic nature.

However, some of the figures were low enough to satisfy Resolution 357/2005 [8]. These probably resulted from the hydrodynamics and the decomposition process that occurs naturally in Javary Lake. At some points, farther from where raw sewage flows into the Lake, the processes of sedimentation, decomposition, dilution, mixture, and circulation appears to alleviate the contamination.

The concentration of $\mathrm{NH}_{3}$ (free ammonia) toxic to fish and other aquatic organisms is determined by the level of $\mathrm{pH}$. For $\mathrm{pH}$ values $<8$, practically all the ammonia is in the form of $\mathrm{NH}_{4}{ }^{+}$(which is less toxic); for $\mathrm{pH}$ equal to 9.5, half the ammonia is in the form of $\mathrm{NH}_{3}$ and the other half in the form of $\mathrm{NH}_{4}$; and for $\mathrm{pH}>11$, practically all the ammonia is in the form of $\mathrm{NH}_{3}$. Based on the ammonia and $\mathrm{pH}$ values in Javary Lake, the ammonia levels pose a substantial risk to fish, because the highest levels of total ammonia nitrogen were obtained at points where the $\mathrm{pH}$ values were low.

In 2010, a cleaning-up project was designed for Javary Lake. To verify if the results from the 2007 and 2008 still persisted, nine new samples were collected before the sewage treatment system started operating. In this new series of nine water samples, 90 fecal coliform analysis were taken in the same 10 points along the Lake shoreline (Table 3).

The results indicated that only less than half (43 results) of the results met the water balneability criteria (recreational water). It is worth to mention that points 2 and 3, located in sites that receive rain water and raw sewage, were the ones with the highest values in all samples. Those sites at the entrance of Javary Lake contribute to its pollution. On the other hand, point 8, in the middle of Lake, and points 7 and 10, far from the discharge areas, were less polluted. 
Table 3: Fecal coliforms.

\begin{tabular}{cccccccccc}
\hline \multicolumn{7}{c}{ Fecal coliforms colonies per 100 mL } \\
\hline \multicolumn{7}{c}{$2010-$ Collection } \\
Point & 1 st & 2nd & 3rd & 4th & 5 th & 6th & 7 th & 8th & 9 th \\
\hline 1 & 530 & 530 & 150 & 1.200 & 180 & 7.300 & 240 & 1.280 & 840 \\
2 & 176,000 & $*$ OS & 128.000 & $*$ OS & $*$ OS & $*$ OS & $*$ OS & 26.000 & 156.000 \\
3 & 112.000 & $*$ OS & $*$ OS & 120.000 & $*$ OS & $*$ OS & $*$ OS & 98.000 & $*$ OS \\
4 & 6.100 & $*$ OS & 320 & 80.000 & $*$ OS & $*$ OS & 170 & 76.000 & 195.000 \\
5 & 5.600 & 7.000 & 810 & 3.100 & 4.200 & 23.000 & 80 & 52.000 & 127.000 \\
6 & 5.700 & 60 & 160 & 420 & 4.100 & 2.000 & 230 & 1.400 & 270 \\
7 & 100 & 100 & 60 & 160 & 510 & 150 & 70 & 960 & 450 \\
8 & 10 & 40 & 10 & 140 & 90 & 220 & 70 & 830 & 660 \\
9 & 12.600 & 2.300 & 760 & 2.800 & 3.000 & $*$ OS & 77.000 & 1.300 & 7.000 \\
10 & 10 & 20 & $<10$ & 120 & 160 & 160 & 140 & 1.000 & 600 \\
\hline
\end{tabular}

$*$ OS (out of scale, result $>300,000$ ).

\subsection{Follow-up results -2011}

In 2011, just after the sanitation collection system started the operation (almost all residences in Lake's surrounding area were connected to the system) and the launch of the sewage treatment facility, there was an attempt to dredge the organic material deposited at the bottom of the Lake. This attempt was interrupted after a few days, due to huge fish mortality. After that, the color of the water in the Lake changed to a bluish-green, indicating the presence of a large number of algae, especially cyanobacteria.

Two new samples collections were scheduled at the end of 2011 to analyze those anthropogenic and antagonic interferences, notably reducing the organic load discharge by collecting and treating domestic raw sewage and introducing organic load from sludge revolvement.

In 2011, to assess the organic load existent in the water, instead of the membrane filtration method, the enzymatic method (Colilert) was used. In this case, E. coli results were obtained instead of fecal coliforms. Since E. coli is not the only bacteria group of the thermo-tolerant coliform, the maximum acceptable value for a water body to be considered suitable for balneability (primary contact and recreational water) is lower than the one related to fecal coliform. According to Resolution 274/00, the legal limit for 1,000 fecal coliform/100 mL corresponds to 800 E. coli/100 mL.

In these two samples, several results were above the maximum allowed $E$. coli value per $100 \mathrm{~mL}$, comparable of the results obtained in the 2007, 2008, and 2010 sample runs (Table 4). Thus, these new results did not indicate significant differences between the 2011 organic load results and those obtained in 2007, 2008, and 2010 (before sanitation system and sludge removal). It can be inferred that each environmental impact (positive and negative) caused by the two anthropogenic interferences (collection and treatment of domestic sewage and sludge revolvement) offset each other, retaining the Javary Lake with the same 'polluted' status.

However, a reduction of organic load discharge does not lead to an immediate decontamination of the water body; it is a slow biological process (Fig. 1). In the case of Javary Lake, as a lentic water body (small water renovation), the natural biological process of decontamination is even slower. This way, suitable water quality results could not be expected in short term. 
Table 4: Most probable number.

\begin{tabular}{ccc}
\hline \multicolumn{3}{c}{ MPN from E. coli per $100 \mathrm{~mL}-2011$} \\
\hline Point/Collection & 1 st & 2nd \\
\hline 1 & $<1^{*}$ & 1.990 \\
2 & 51.700 & 550 \\
4 & 200 & 88.000 \\
5 & 4.569 .000 & 361.000 \\
6 & 1.100 & 820 \\
7 & 200 & 820 \\
8 & $<1^{*}$ & 390 \\
9 & 800 & 3.870 \\
10 & $<1^{*}$ & 510 \\
\hline
\end{tabular}

*In the first collection, null results of $E$. coli were obtained at points 1,8 , and 10 , being the smallest dilution $10^{-2}$. This dilution leads to obtaining null results as most probable number (MNP), if they were $<100$. Thus, it is most likely that there has been an MPN value of $<100$ and not null. In the second collection, lower dilutions were analyzed, based on what was learned from the previous collect.

Nevertheless, the results should have shown at least a trend of improvement in water quality, which actually did not happen. Contribute, negatively, to this phenomenon (maintenance of water quality as 'polluted') is the environmental impact of suspending solids from the bottom of the Lake. Obviously, there was an increase of organic load in the water caused by the attempt of dredging the sludge. However, this negative environmental impact is only temporary, which would be reduced by settling down this organic load, again, at the bottom of the Lake.

Besides the analysis of organic load, other tests were also made at the same points. It can be noted that point 3 was excluded from the analysis because it was grounded during the construction of the collection system.

In Table 5, it can be seen that the results of the DO, from the samples collected in the Lake, points $1,6,7,8,9$, and 10 presented very high values. These results were associated with the presence of algae, which use the organic matter already in the Lake and was put in suspension due to the dredge of the sludge. In the samples collected in the Lake, high $\mathrm{pH}$ values were obtained, which is consistent with the algal bloom.

As shown in the Table 5, the negative results of the oxidation-reduction potential (ORP) analysis of the samples collected in the Lake are associated with the process of anaerobic decomposition of organic matter that occurs in the Lake. ORP values above 50 mVolts are associated with aerobic conditions, typical of unpolluted water bodies. ORP values below -50 mVolts are associated with anaerobic conditions, being the values equal to or smaller than 200 mVolts associated with the formation of methane in marshes and in sewage treatment facilities.

The range of ORP values from -50 to 50 mVolts is associated to anoxic conditions, where anaerobic and facultative bacteria are developed, such as fecal coliform. The latter ones are responsible 
Table 5: DO (mg/L), saturation percentage, $\mathrm{pH}$ e ORP.

\begin{tabular}{|c|c|c|c|c|c|c|c|c|}
\hline \multicolumn{9}{|c|}{ DO (mg/L), saturation percentage, $\mathrm{pH}$ e ORP } \\
\hline \multirow[b]{3}{*}{ Point } & \multicolumn{8}{|c|}{2011} \\
\hline & \multicolumn{4}{|c|}{$1 \mathrm{st}$} & \multicolumn{4}{|c|}{ 2nd } \\
\hline & OD & Sat $\%$ & $\mathrm{pH}$ & ORP & OD & Sat $\%$ & $\mathrm{pH}$ & ORP \\
\hline 1 & 10,54 & 122,9 & 9,45 & $-48,80$ & 11,17 & 144,8 & 8,69 & 75,5 \\
\hline 2 & 0,72 & 8,50 & 7,13 & $-173,5$ & 4,89 & 61,8 & 7,38 & $-101,6$ \\
\hline 4 & 5,33 & 58,1 & 6,97 & $-64,5$ & 1,5 & 18,0 & 7,51 & $-177,6$ \\
\hline 5 & 0,98 & 11,0 & 7,08 & $-190,1$ & 2,66 & 32,44 & 7,28 & 91,0 \\
\hline 6 & 9,18 & 106,4 & 9,21 & $-92,1$ & 9,76 & 124,8 & 8,37 & $-81,2$ \\
\hline 7 & 8,82 & 103,6 & 9,49 & $-23,3$ & 8,09 & 101,1 & 8,08 & $-90,8$ \\
\hline 8 & 9,84 & 116,5 & 9,43 & $-48,9$ & 11,17 & 143,1 & 8,83 & $-8,2$ \\
\hline 9 & 10,88 & 126,7 & 9,38 & $-41,2$ & 7,72 & 101,9 & 8,21 & 45,2 \\
\hline 10 & 11,11 & 131,0 & 9,49 & $-58,0$ & 8,58 & 108,7 & 8,32 & $-46,6$ \\
\hline
\end{tabular}

for the reduction of nitrate to nitrite and latter on to gaseous nitrogen, in sewage treatment facilities with nitrogen removal.

Considering these results, it was found that in Javary Lake decomposition processes is similar to those occurring in stabilization ponds (Fig. 1). Despite the huge algae bloom that increases ORP, the organic matter in suspension due to the dredging process exceeded the algae contribution to ORP values increase, resulting in negative ORP values. If there would be no more raw sewage discharge in the Lake, the sludge would deposit on the bottom, tending the ORP values to become positive and the algae population to decline due to lack of nutrients (organic matter).

Table 6 shows that the nitrogen results obtained were clearly smaller than those obtained in the 2007 and 2008 collections. Only points 4 and 5 showed high levels of ammoniac nitrogen. They are close to discharge for rain drainage pipeline, potentially contaminated with sewage. The reduced quantity of ammoniac nitrogen values in the innermost part of the Lake that could be attributed to the nitrate oxidation, which happens due to the availability of DO. High levels of DO can be attributed to the algae presence.

Table 6 also indicate the phosphate values in the form of orthophosphate $\left(\mathrm{PO}_{4}{ }^{3-}\right)$ which is quickly absorbed by algae and other microorganisms. Orthophosphate were not found in samples collected at the innermost part of the Lake. This fact is a result of the consumption (nutrients) of all the orthophosphate released in the Lake due to the decomposition of compounds containing phosphorus discharged through the sewers. Phosphorus is present in sewage in the form of fatty acids (human excretion) and polyphosphates (found in laundry detergents and soaps).

At points 1 and 4, high levels of phosphate were found, probably associated with sewage contamination. The absence of phosphorus in most samples collected from the Lake should be related to phosphorus being a nutrient for the process of eutrophication. This way, a sewage treatment system, that discharge its effluents in water, should have a process of reducing presence of phosphorus to reduce the eutrophication trend of the water resource.

Table 7 show the values of $\mathrm{BOD}_{5}, \mathrm{COD}$, and $\mathrm{COD} / \mathrm{BOD}_{5}$. Even though $\mathrm{BOD}_{5}$ values were greater than the maximum values set by Resolution 357/2005, for classes 1 and 2, these were lower than those obtained from the samples collected in 2007 and 2008. 
Table 6: N-NH3 and $\mathrm{PO}_{4}{ }^{3-}$ analysis (mg/L).

\begin{tabular}{ccc}
\hline \multicolumn{3}{c}{ Second sample of 2011} \\
\hline Point & $\begin{array}{c}\mathrm{N}^{-N_{3} \text { Analysis }}(\mathrm{mg} / \mathrm{L}) \\
1\end{array}$ & $\begin{array}{c}\mathrm{PO}_{4}^{3-} \text { analysis } \\
(\mathrm{mg} / \mathrm{L})\end{array}$ \\
\hline 2 & 0,15 & 7,11 \\
4 & 0,06 & 0,00 \\
5 & 4,41 & 3,21 \\
6 & 4,13 & 0,00 \\
7 & 0,44 & 0,00 \\
8 & 0,03 & 0,00 \\
9 & 0,04 & 0,00 \\
10 & 0,26 & 0,00 \\
\hline
\end{tabular}

Table 7: $\mathrm{BOD}_{5}(\mathrm{mg} / \mathrm{L}), \mathrm{COD}(\mathrm{mg} / \mathrm{L})$, and $\mathrm{COD} / \mathrm{BOD}_{5}$.

$\mathrm{BOD}_{5}(\mathrm{mg} / \mathrm{L}), \mathrm{COD}(\mathrm{mg} / \mathrm{L})$, and COD/BOD 5

\begin{tabular}{cccc}
\hline \multicolumn{3}{c}{2011} \\
\hline \multirow{3}{*}{ 2nd collection } \\
\cline { 2 - 4 } Point & BOD $_{5}$ & COD & COD/BOD $_{5}$ \\
\hline 1 & 14 & 26 & 1,86 \\
2 & 14 & 22 & 1,57 \\
3 & 12 & 25 & 2,08 \\
4 & 13 & $<20$ & $<1,54$ \\
5 & 12 & 23 & 1,92 \\
6 & 18 & 27 & 1,50 \\
7 & 11 & 25 & 2,27 \\
8 & 11 & 23 & 2,09 \\
9 & 7 & $<20$ & $<2,86$ \\
10 & 17 & 22 & 1,29 \\
\hline
\end{tabular}

The COD values obtained were considerably lower than those obtained in 2007 and 2008. The ratio $\mathrm{COD} / \mathrm{BOD}_{5}$ presented values smaller than 2.4 , indicating that the discharge of industrial effluents was not significant. The ratio COD/BOD ${ }_{5}$ at point 9 in the second phase of 2011 collection could not be considered meaningful as the threshold quantification restrictions of the analytical method used in the analysis of COD is $20 \mathrm{mg} / \mathrm{L}$. The threshold of quantification is the lowest concentration that can be achieved through an analytical method with acceptable accuracy (analytical error). 


\section{DISCUSSION}

Over decades, large amounts of raw domestic sewage were discharge directly into the Javary Lake. A great part of the organic matter introduced in the Lake was consumed by organisms or has already biodegraded. A cleaning-up project is in course to manage water quality in the Javary Lake. Currently, the domestic raw sewage has been collected and treated properly. However, it might take a long time before the water quality in the Lake reach legal standards naturally.

Small lakes tend to saturate very quickly, due to bacterial and algal reproduction (new and dead cells) during the decomposition of organic matter. The degradation of organic matter is relatively slow and an excessive amount of nutrients produces a large amount of sludge loaded of microorganisms, which is settled in bottom of the Lake $[18,19]$.

For many years, a significant portion of the suspended solids (sludge) was deposited on the bottom of the Lake resulting in an accumulated layer of organic matter of over $1.5 \mathrm{~m}$ all around the $80,000 \mathrm{~m}^{2}$ Lake area. A second phase of the cleaning-up project has already been planned to remove this $120,000 \mathrm{~m}^{3}$ of sludge. The sludge reduces the total volume of water in the Lake by almost $50 \%$, making the natural biological process even slower.

The first attempt to dredge the sludge from the bottom resulted in algae bloom, steady pollution, eutrophication, and fish death. There are other environmental impacts associated with sludge removal, that is, the huge amount of solid waste generated in the removal process is an environmental hazard itself, becoming a waste management disposal problem, especially for a small municipality.

The results of this study indicated that Javary Lake is still a polluted water resource, mainly due to organic matter. The main assumption of this study is that Javary Lake has been biologically operating as a stabilization pond, as it is schematically represented in Fig. 1. Stabilization pond is a natural biological treatment process of polluted water where living organisms (bacteria and algae) use organic matter as food $[18,19]$.

The biological process concept of stabilization ponds works perfectly for describing how the raw domestic sewage discharged directly in the Javary Lake has being decomposed. Natural stabilization ponds are one of the nature's most economical ways for treating polluted water.

After any raw sewage discharge, the aerobic, facultative, and anaerobic decompositions of the organic matter begins. This decomposition process needs oxygen to be supported. Oxygen is provided directly into the water across the surface area and from photosynthesis (when sun is present), see Fig. $1[18,19]$.

The aerobic bacteria use oxygen to break down organic matter suspended in the water producing carbon dioxide, which is used by algae in the photosynthesis process. According to the biological cycle, heterotrophic bacteria use oxygen to decompose organic matter in the polluted water, producing new bacteria and nutrients. These products stimulate algae growth in the Lake, which in the presence of sunlight consumes carbon dioxide producing new algae and oxygen.

The results of this study indicated that the recent implemented sewage treatment system (collection and treatment) was not sufficient for improving the water quality. Dredging the sludge is a necessary step toward this desired outcome.

Sludge in the bottom of Javary Lake, as in any stabilization pond, needs to be removed every 20 to 30 years to improve the efficiency of the natural biological process (Fig. 1). However, revolving the bottom of the Lake to remove sludge will introduce a huge amount of already deposited compounds and organic matter in the water.

Therefore, even though dredging is a necessary step, it will create a huge temporary pollution. There would be a need for polluting Javary Lake before it would finally reach the water quality required by legal standards for its use. 
There are many other problems associated with natural stabilization ponds. They require long detention time and large areas for an adequate and efficient treatment. It also requires frequent monitoring for parameters, such as $\mathrm{pH}$ and DO.

The stabilization pond depth is another important factor. Depth must be $>0.5 \mathrm{~m}$ to exclude plant growth in the bottom. A depth of over $2.5 \mathrm{~m}$ stimulates anaerobic conditions to occur. Usually, natural stabilization ponds have variable water depth along their areas. The water layer at Javary Lake varies from $1 \mathrm{~m}$ close to the shoreline to $4 \mathrm{~m}$ in the middle.

In Javary Lake, similar to a facultative stabilization pond, the aerobic zone is near (up to $1 \mathrm{~m}$ ) to the water surface, anoxic layer in the middle, and the anaerobic zone in deeper waters (over $2.5 \mathrm{~m}$ depth). In the aerobic zone, all biological activity is aerobic decomposition. The anaerobic zone, which is closer to the bottom, accommodates processes based on the absence of oxygen, hosting anaerobic and facultative bacteria.

In Javary Lake, because water layers vary, in locations with over $1 \mathrm{~m}$ in depth, the concentration of DO will vary along the day (morning, afternoon, and evening) and the season (warm and cold). In any part of the Lake (aerobic, anoxic, and anaerobic), when the level of DO drops, the aerobic and facultative bacteria reduce, stimulating unpleasant conditions associated with the anaerobic decomposition.

The anaerobic zone also holds the organic matter (sludge) deposited on the bottom of the Lake. Due to the lack of oxygen, these solids were broken down by anaerobic bacteria producing methane or hydrogen sulfide. That is why the sludge on the bottom of a pond smells like sulfur when revolved.

Excessive amount of nutrients (specially, nitrogen and phosphorus) are a common problem in lakes. They can cause excessive growth of aquatic plants, bacteria growth, and algae bloom, especially in warm seasons. This study found high nutrient levels in the Javary Lake indicated by the values found of ammonia, nitrate, and phosphate.

Another problem associated with stabilization ponds is algal bloom as it occurred from time to time at Javary Lake. Water contaminated with organic matter is a perfect environment for algae to reproduce. During the daylight, if nutrients and sunlight are readily available, algae number can grow very quickly. During the night, these large quantities of algae consume DO and continue to reproduce.

Algae blooms elevate the $\mathrm{pH}$ levels and influence the DO in the water (elevate during the day; reduce during the night). Algae are organisms dependent on sunlight, existing in clear and shallow waters. However, an algae bloom tends to resolve itself. Algae grow and reproduce consuming nutrients. If a nutrient depletion occurs, algae will have no nutrients and will die. Dead algae promote bacterial bloom. This bacteria growth drops the DO level in the water transforming the system in anaerobic $[18,19]$.

Fish death may be an indicator of this influence on DO due to algae bloom. Oxygen consumption (bacteria growth and algae use during the night) and organic matter decomposition reduces the level of DO in the water. Fish and other aerobic organisms require oxygen to live. If the reduction of DO would be high enough, it might kill fish and other aquatic life. The proper balance in the aquatic environment is essential for the survival of all living organisms.

However, there is also an antagonist effect associated with the presence of fish in polluted waters. Even though, algae may be toxic and consume DO during the night, some fish, such as carp, eat algae, helping to prevent algal bloom.

The biological processes are also influenced by temperature changes, indicating that water quality depends on the season. During summer time, higher temperatures and longer daylights boost $\mathrm{BOD}_{5}$ removal. In contrast, during winter time, the BOD removal tends to be poorer. High BOD values indicate presence of organic matter. Oxygen depletion is a natural consequence associate with high BOD. The higher the domestic sewage BOD, the higher its polluting power.

In Javary Lake, an important health risk associated to harmful algae bloom is contamination by cyanotoxins, which can be produced by cyanobacteria. Cyanobacteria can be found in almost every 
environment (e.g. lakes and oceans) and their bloom can produce harmful cyanotoxins in concentrations sufficient to kill animals and humans. These toxins are so powerful that even mild recreational exposure to cyanobacteria can cause several diseases.

Although cyanobacteria (blue-green algae) are similar to algae, they are not really an algae. They are simple life forms more closely related to bacteria. The risk of health problem is much higher, if a human is exposed directly to an organism. That is the main reason for legislations to classify WQSs according to their use. The acceptable levels of organisms in a water resource will depend upon the intended use.

Fecal coliforms, as facultative bacteria, can live in both aerobic and anaerobic zones. They are universally present in the feces of warm-blooded animals, making them commonly found in any natural aquatic environment, in soil and on vegetation. Even though, a sewage collection and a treatment facility were implemented in Javary Lake, no sanitation system can avoid the presence of fecal coliforms in natural resource waters. The results of this study indicated that Javary Lake is still polluted and contaminated mainly by fecal coliforms.

\section{CONCLUSIONS}

In Brazil, due to the lack of adequate sewage collection and treatment systems, it is common for untreated domestic sewage to be discharged directly into water bodies. The object of this study was a polluted water resource, called Javary Lake, located in small pleasant municipality of southeastern Brazil.

Over decades, large amounts of raw domestic sewage were discharge directly into the Javary Lake. A great part of the organic matter introduced in the Lake was consumed by organisms or has already biodegraded. This progressive degradation threatens to undermine its economic value and also poses a serious risk to environment and human health. The preliminary results of this study from 2007 to 2010 corroborated the 'polluted' status for the Javary Lake.

These results were based on physico-chemical and microbiological analyses, demonstrating that the Lake was mainly polluted by organic matter (domestic sewage). In some areas, the contamination found was so severe that it could be characterized as typical of 'strong sewage'.

Among the parameters analyzed, the high levels of DO stood out. These levels indicated intense production of oxygen by algae bloom. High oxygen concentration impeded the occurrence of offensive odors, typical of anaerobic environments, and favors biodegradation of organic material, but high eutrophication can lead to algal blooms and consequent contamination by cyanotoxins.

Despite the wide variation in some cases, an aggregate analyzes of the overall results indicated that they were similar to those typically observed in stabilization ponds. These results support the main assumption of this study that Javary Lake has been biologically operated as a stabilization pond for a long time (Fig. 1). The biological process concept of stabilization ponds works perfectly for describing how the raw domestic sewage discharged directly in the Javary Lake has being decomposed and accumulated over the years.

There is an ongoing public project to clean up Javary Lake. Currently, there are no more domestic raw sewages being directly discharged. They have been collected and treated properly. However, as biological processes operate very slowly, it might take a long time before the water quality in the Lake reach legal standards naturally.

Over these many years, a significant portion of the suspended solids (sludge) has deposited on the bottom of the Lake, resulting in an accumulated layer of organic matter of over $1.5 \mathrm{~m}$ all around the $80,000 \mathrm{~m}^{2}$ Lake area.

In 2011, after the first part of the cleaning-up project was concluded, there was an attempt to remove the accumulated sludge from the bottom of the Javary Lake. This sludge removal introduced already settled organic matter into the water, generating algae bloom and fish death. A few days later, the sludge dredging was interrupted. 
Despite of the implementation of the cleaning-up project, there is a still worrying deterioration of the water quality in Javary Lake. The results of this study indicated that Javary Lake is still a 'polluted' water resource, primarily by organic matter. The Lake eutrophication combined with a process of deposition of sludge can even lead to a future condition of anaerobiosis.

To reverse this situation, it is still necessary to control the sewage treatment system and dredge the Lake bottom to remove the accumulated sludge. It is still under evaluation which would be the best alternative for finally cleaning up the Javary Lake and for disposing the sludge. Till date, Javary Lake still keeps its 'polluted' status. It is still pending further studies to determine the most efficient approach for managing the water quality in the Lake.

\section{REFERENCES}

[1] Rebouças, A.C., Água Doce no Mundo e no Brasil, in Águas Doces no Brasil: capital ecológico, uso e conservação, capítulo 1 3a edição, Escrituras Editora, pp. 1-35, 2006.

[2] Braga, B.P.F., Flecha, R., Thomas, P., Cardoso, W., Coelho, A. C., Integrated Water Resources Management in a Federative Country: the case of Brazil, International Journal of Water Resources Development, Routledge, 25(4), 611-628, 2009.

[3] National Water Agency (ANA-Agência Nacional de Águas), Conjuntura dos Recursos Hídricos no Brasil, Brasília, 2009, avaiable at: http://www.ana.gov.br/

[4] National Water Agency (ANA-Agência Nacional de Águas), Conjuntura dos Recursos Hídricos no Brasil, Brasília, 2010, avaiable at: http://www.ana.gov.br/

[5] National Water Agency (ANA-Agência Nacional de Águas), Conjuntura dos Recursos Hídricos no Brasil, Brasília, 2011, avaiable at: http://www.ana.gov.br/

[6] Brazilian Institute of Geography and Statistics (IBGE - Instituto Brasileiro de Geografia e Estatística), Brazilian National Survey of Basic Sanitation (PNSB), 2008, avaiable at: http://www.ibge.org.br

[7] Federal Law 11.445 (1997) Available at http://www.planalto.gov.br/

[8] National Environmental Council (CONAMA - Conselho Nacional de Meio Ambiente), Resolution 357/2005, Avaiable at: http://www.mma.gov.br/conama

[9] Braga, Benedito et al., Introdução à engenharia ambiental, São Paulo: Prentice Hall, 2002.

[10] National Environmental Council (CONAMA - Conselho Nacional de Meio Ambiente). Resolution 430/2011, avaiable at: http://www.mma.gov.br/conama

[11] Ministério da Saúde (Ministry of Health). Portaria 518/2004, avaiable at: http://www.saude. gov.br/portaria 518 .

[12] National Environmental Council (CONAMA - Conselho Nacional de Meio Ambiente). Resolution 274/2000, available at: http://www.mma.gov.br/conama.

[13] Rio de Janeiro Auditing Authority (TCE), Socioeconomics Study 2005 (in portuguese), Miguel Pereira, available at: www.tce.rj.gov.br

[14] Standard Methods (SM), American Public Health Association (APHA), the American Water Works Association (AWWA), and the Water Environment Federation (WEF), Standard Methods for the Examination of Water and Wastewater, 21 ed. 2005.

[15] Metcalf \& Eddy, Wastewater Engineering. Treatment and Reuse, 4 ed., McGraw-Hill, 2006.

[16] Veiga, M.M., Silva, Dalton M., Water quality analysis at Javary Lake, Rio de Janeiro: Brazil. WIT Transactions on Ecology and the Environment (Online), 145, p. 22094, 2011.

[17] Von Sperling, M., Introduction to water quality and wastewater treatment (in portuguese), $1\left(3^{a}\right)$ ed. Ed. DESA. 2005.

[18] Von Sperling, M., Stabiization Ponds. (in portuguese) 2nd ed. 2006, p. 196, Ed. UFMG

[19] Vesilind. P.A, Peirce. J.J., Weiner \& Ruth F., Environmental Engineering, 3rd ed. 1994. 